\title{
20302 微細管内における相変化過程における流動遷移に関する研究 Study on phase change in microchannel tube
}

\author{
○学 金 栄 (筑波大院) \\ 正 阿部 豊（筑波大） \\ 正金子 暁子（筑波大） \\ 鈴木＼cjkstart裕（WELCON Co. Ltd.）
}

Rong Jin, Akiko KANEKO and Yutaka ABE, University of Tsukuba, 1-1-1 Tennodai, Tsukuba, Ibaraki Yutaka SUZUKI, WELCON Co. Ltd., 15-1 Yashiroda, Akiha-ku, Niigata, Niigata

\begin{abstract}
At present, microchannel heat exchanger is requested to achieve miniaturization and high efficiency in small size energy equipment. In author group's previous studies, the prototype of microchannel heat exchanger could reach the heat transfer rate of $8 \mathrm{~kW}$ despite the weight of $230 \mathrm{~g}$. In order to clarify the heat transfer mechanism in microchannel heat exchanger, it is necessary to study about the thermal hydraulic characteristics of phase-change flow. As the results, annular flow, injection flow and bubbly flow, three main flow regimes were identified with the phase change of condensation. During the boiling experiments, bubbly flow, slug flow, annular flow three main flow regimes were observed. Based on the experiment results and image processing, hydraulic and thermal parameters were determined such as heat transfer coefficient, void fraction and velocity of bubbles.
\end{abstract}

Key Words: Microchannel heat exchanger, Visualization, Flow pattern, Condensation, Boiling

\section{1. 緒言}

現在, 燃料電池や $\mathrm{CO}_{2}$ 冷媒ヒートポンプなどに代表され る小型エネルギー機器において高効率を達成するためには, 熱交換器の小型化及び高効率化が求められている.しかし, 一般的に従来型の熱交換器は大型化することで効率を向上 させることが多く, システムのサイズは熱交換器に支配さ れていると言える．著者らが拡散接合技術により製作した マイクロチャンネル熱交換器は, 既存の熱交換器の $1 / 100$ 程度の大きさであるにも関わらず，同程度以上の熱交換量 を達成することが確認されている ${ }^{[1]}$. この熱交換器の伝熱 メカニズムを解明し, 微細管内の凝縮・沸騰に関する詳細 な動作特性の解明が必要となる。しかし，微細流路内の可 視化ができないことや流路が積層しているなど，熱交換器 内部の伝熱流動特性の解明が困難であった。本研究では微 細管内における凝縮・沸騰に関して流動構造および伝熱特 性を明らかにすることを目的とする．管内流れが可視化計 測するために, 透明な円形と矩形ガラス微細管を実験対象 とする. 凝縮実験では微細管を低温水槽内に浸し, 蒸気を 流入させることで蒸気流の凝縮挙動の可視化を行った．同 様に, 微細管外高温水で, 管内低温水を沸騰させる沸騰実験 を行った．更に可視化結果により，各流動パターン及び伝 熱性能評価を行った。

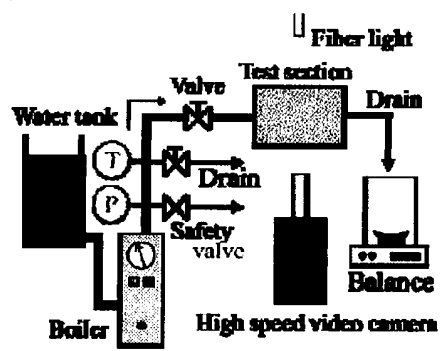

(a) Schematic diagram

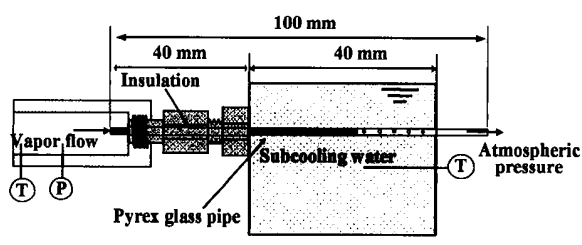

(b) Test section

Fig. 1 Experimental apparatus of condensation

\section{2. 凝縮実験装置及び実験方法}

微細管を用いた凝縮実験のための装置を Fig. 1 に示す. Fig. 1(a)に全体概略図を示す, 実験装置は主に電気ボイラー, テスト部, ハイスピードビデオカメラ, 計測機器から構成 されている. Fig. 1(b)にテスト部の詳細を示す. 用いたガ ラス微細管全長は $100 \mathrm{~mm}$, 水槽内凝縮部の長さは $40 \mathrm{~mm}$ とする。

実験方法を以下に示す．脱気装置によりタンク内の水を 脱気し，電気ボイラーに水を送り込む. 電気ボイラーによ り蒸気を発生させ, ドレインで蒸気の圧力を調整し, テス 卜部に流入させる．温度と圧力はテスト部直前で計測し， テスト部内で凝縮した水は電子天秤により計測される．実 験条件は円形と矩形ガラス管内径/外径 500/800 $\mu \mathrm{m}, 240 /$ $400 \mu \mathrm{m}$, 冷却水温 $25 \pm 1^{\circ} \mathrm{C}$, 入口蒸気圧力 $104 \sim 170 \mathrm{kPa}$, 実 験用水溶存酸素量 $1.5 \mathrm{mg} \mathrm{L}^{-1}$ とした.

\section{3. 凝縮実験の結果と考察}

微細管における蒸気の凝縮挙動を Fig. 2 に示す. Fig. 2(a) に微細管全体の流動を示している。蒸気は図の左側から流 れ，ガラス管壁面からの熱伝達によって凝縮している．凝 縮現象を詳細に観測するために，図中の $\mathrm{A} \sim \mathrm{D}$ 点における 局所画像をそれぞれ Fig. 2(A)〜2(D)に示す. Fig. 2(A)は滑 らかな環状流, Fig. 2(B)は波立つの環状流, Fig. 2(C)はくび れが分裂し、スラグ流から気泡が生成する噴出流, Fig. 2(D) は気泡流へ遷移する様子を示している.

微細管入口直前の各ドレインの調節により，蒸気のゲー ジ圧力を数 $\mathrm{kPa}$ 数十 $\mathrm{kPa}$ の範囲で調整する. 円形微細管内 蒸気レイノルズ数は(1)式で定義される.ここで $W$ は単位時 間凝縮水量， $D$ は円形微細管の直径を示している.

$$
\operatorname{Re}_{v}=\frac{u_{v} D}{\mu / \rho}=\frac{\frac{W}{\rho A} D}{\mu / \rho}=\frac{4 W}{D \pi \mu}
$$

環状流及び噴出流領域では, 蒸気 $R e_{y}$ 数の増加に伴う各 仕様の微細管の環状流長さ及び環状流先端部分裂周波数は 増加することが確認された。 
(a)

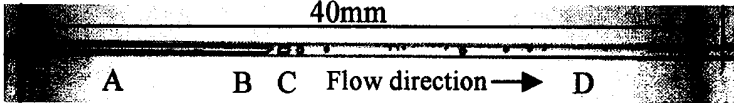

(A)

(B)

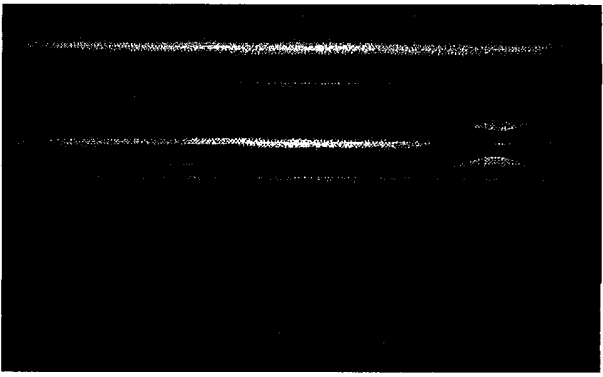

Fig. 2 Condensation behavior in the capillary glass tube $\left(D=500 \mu \mathrm{m}, P_{v, i n}=105.8 \mathrm{kPa}, R e_{v}=754\right)$

円形，矩形微細管熱通過率は式(2)，(3)で定義される.

$$
\begin{aligned}
U_{a n n c} & =\frac{H_{f g} W}{\pi D L_{a n n}\left(T_{\text {sat }}-T_{\text {water }}\right)} \\
U_{\text {anns }} & =\frac{H_{f g} W}{4 a L_{\text {ann }}\left(T_{\text {sat }}-T_{\text {water }}\right)}
\end{aligned}
$$

ここで $H_{f 8}$ は蒸気の凝縮潜熱，Wは単位時間凝縮水量， $D$ と $a$ は微細管の内径と内辺長, Lann は環状流の長さ, $T_{\text {water }}$ はサブクール水の水温を示している. Fig.3のように, レイ ノルズ数の増加に伴い, 凝縮熱伝達率は減少していること が確認できる。レイノルズ数が上昇することで環状流長さ は増加し，伝熱面積も増加する。これにより凝縮熱伝達率 が低くても十分な熱量を得ることができると考えられる.

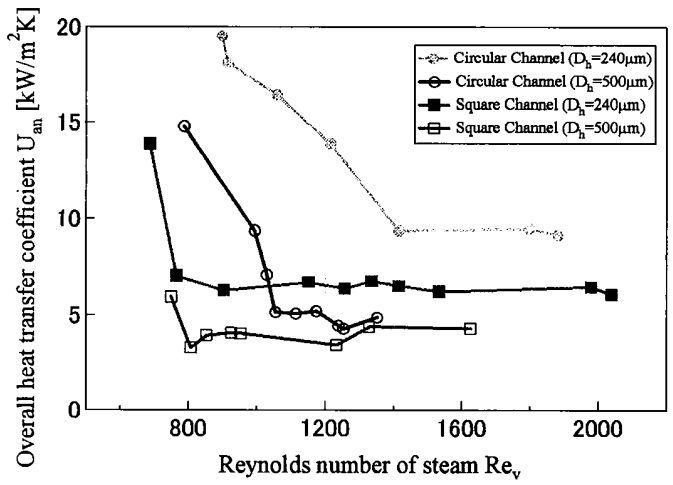

Fig. 3 Overall heat transfer coefficient in annular flow regime

\section{4. 沸騰実験装置及び実験方法}

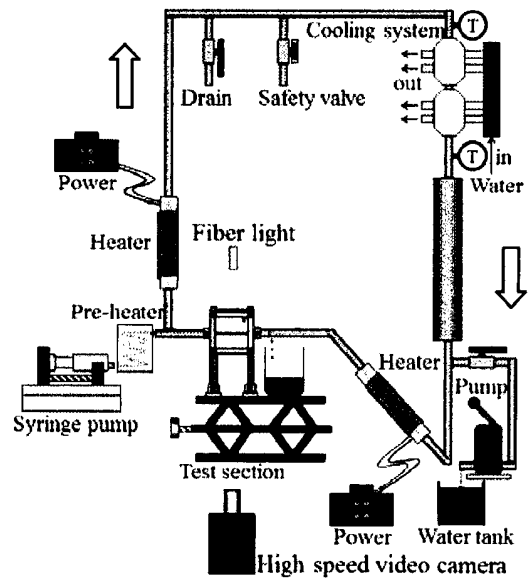

Fig. 4 Experimental apparatus of boiling
Fig. 4 に沸騰実験装置概略図を示す。実験装置は主に加 熱部, 冷却部, テス卜部, 計測機器から構成されている. 水をポンプにより循環路内に流入させ，密封する．ヒータ により循環路内の水を加熱し, 冷却器により水を冷却する ことで，自然循環を発生させ，管路内の水を昇温させる。 テスト部内 $120^{\circ} \mathrm{C}$ 高温水で微細管内 $50^{\circ} \mathrm{C}$ 低温水を加熱, 沸騰させる. 実験条件は円形ガラス管内径/外径 500/ 800 $\mu \mathrm{m}, 240 / 400 \mu \mathrm{m}$, 水槽内水温 $120 \sim 130^{\circ} \mathrm{C}$, 圧力 $300 \sim 400 \mathrm{kPa}$, 微細管入口低温水流量 $15 \sim 70 \mathrm{~kg} \mathrm{~m}^{-2} \mathrm{~s}^{-1}$ 実験用水溶存酸素量 $1.5 \mathrm{mg} \mathrm{L}^{-1}$ とする.

\section{5. 沸騰実験の結果と考察}

微細管における水の沸騰挙動を Fig. 5 に示す. 二枚連続 な写真の時間差は $1 \mathrm{~ms}$ である。蒸気は図の左側から流れ， ガラス管壁面からの熱伝達によって沸騰している.

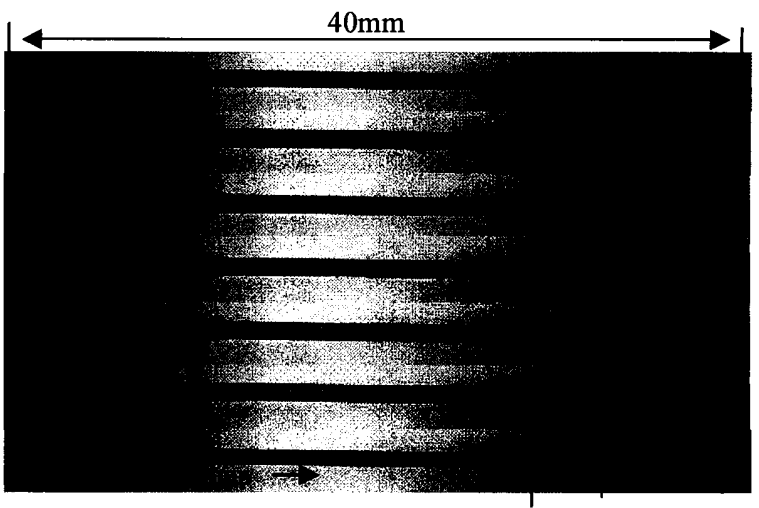

Fig. 5 Boiling behavior in the capillary glass tube ( $D=500 \mu \mathrm{m}, T_{w}=125^{\circ} \mathrm{C}, P_{w}=350 \mathrm{kPa}, G_{w, i n}=40 \mathrm{~kg} \mathrm{~m}^{-2} \mathrm{~s}^{-1}$ )

管内流れは水単相流，気泡流，スラグ流，環状流へ遷移 する様子が確認された. 水単相流に生成した気泡核は一定 時間内維持し，ある瞬間で急速に膨張する現象が確認され た.スラグの急速膨張は形成した気泡が管断面全域を占め, 壁面との伝熱面積が急激に増加すると考えられる.

\section{6. 結言}

微細管内における沸騰凝縮に関して流動構造および伝熱 特性を明らかにすることを目的とし，実験によって以下の 知見を得た

(1) 凝縮実験では，蒸気は環状流から噴出流を経て気泡流 へと流動が遷移する様子が確認された。

(2) 蒸気レイノルズ数が上昇するに伴い凝縮熱量および 環状流長さは増加し, 凝縮熱伝達率は減少する傾向にあ ることが示された。

（3）沸騰実験では, 水は水単相流から, 気泡流、スラグ流 を経て環状流へ遷移する様子が確認された。スラグ膨 張に伴い，熱交換量も急激に増加することが得られた。

\section{参考文献}

(1) Shingo Asaba, Koji liyama, Akiko Kaneko, Yutaka Abe, Yutaka Suzuki, Study on thermal hydraulic characteristics of the stacked high pressure resistance microchannel heat exchanger, Proc. of 11th Int. Conf. on Power Engineering, 2011-55378 pp. 473-480, (2011).

(2) 高峰大河ら,「微細管内における相変化挙動の可視化計 測」オーガナイズド混相流フォーラム講演論文集 2011 